\title{
Pengaruh Kepemimpinan dan Motivasi Kerja Terhadap Kepuasan Kerja Karyawan PT Rahman Teknik Perkasa Bekasi
}

\author{
Ahmad Mubarok ${ }^{1}$, Agustian Zein ${ }^{2}$ \\ ${ }^{1}$ Magister Manajemen Universitas Bhayangkara Jakarta Raya, \\ ahmad.mubarok@yahoo.com ${ }^{1}$ \\ 2Magister Manajemen Universitas Bhayangkara Jakarta Raya, \\ ;agustian.zein@dsn.ubharajaya.ac.id
}

\begin{abstract}
ABSTRAK
Penelitian ini bertujuan untuk menguji pengaruh Kepemimpinan dan Motivasi Kerja terhadap Kepuasan Kerja Karyawan. Kepuasan kerja adalah tentang apa yang membuat seseorang bahagia dalam pekerjaannya. Faktor-faktor yang mempengaruhi kepuasan kerja pegawai adalah faktorfaktor yang berhubungan dengan pekerjaan itu sendiri, dengan kondisi kerja, dengan pimpinan, dengan rekan kerja. Penelitian ini dilakukan pada PT. Rahman Teknik Perkasa Bekasi. Metode penelitian yang digunakan berupa metode penelitian kuantitatif dengan menggunakan Regresi linear sederhana dan berganda. Dari populasi sejumlah 67 orang, dengan menggunakan teknik sampel slovin, diperoleh jumlah sampel sebanyak 40 orang. Hasil pengujian hipotesis menunjukkan adanya pengaruh secara positif dan signifikan dari Kepemimpinan terhadap Kepuasan kerja karyawan. Motivasi memiliki pengaruh secara positif dan signifikan terhadap Kepuasan kerja Karyawan.Kepemimpinan dan Motivasi memiliki pengaruh secara positif dan signifikan terhadap Kepuasan kerja karyawan Karyawan.
\end{abstract}

Kata Kunci: Kepemimpinan, Motivasi, Kepuasan Kerja Karyawan

\section{ABSTRACT}

This study aims to examine the effect of Leadership and Work Motivation on Employee Job Satisfaction. Job satisfaction is about what makes someone happy in their work. Factors that influence employee job satisfaction are factors associated with the work itself, with working conditions, with the leader, with coworkers. This research was conducted at PT. Rahman Teknik Perkasa Bekasi. The research method used is a quantitative research method using simple and multiple linear regression. From a population of 67 people, using the Slovin sample technique, a sample of 40 people was obtained. The results of hypothesis testing indicate a positive and significant influence of leadership on employee job satisfaction. Motivation has a positive and significant influence on Employee Job Satisfaction. Leadership and Motivation have a positive and significant influence on employee job satisfaction.

Kata Kunci: Leadership, Motivation, Satisfaction

Diterima: 17 Des 2018; Direvisi: 14 Feb 2019; Diterbitkan: 15 April 2019

\section{PENDAHULUAN}

Kepuasan kerja adalah tentang apa yang membuat seseorang bahagia dalam pekerjaannya. Faktor-faktor yang mempengaruhi kepuasan kerja pegawai adalah faktor-faktor yang berhubungan dengan pekerjaan itu sendiri, dengan kondisi kerja, dengan pimpinan, dengan rekan kerja, dengan pengawasan, dengan promosi jabatan dan dengan gaji. Seperti yang dituturkan oleh 
dapat menimbulkan sikap apatis dalam bekerja karena tidak memberikan harapan lebih baik di masa depan.

Menurut hasil rangkuman wawancara dengan beberapa karyawan pegawai teknisi: kepuasan gaji dirasa belum mencukupi harapan, karena perusahaan memberikan gaji yang belum layak kepada karyawankaryawannya dan tidak memberikan fasilitasfasilitas di Perusahaan yang membuat saya tidak merasa nyaman. Dalam pemberian gaji, perusahaan tidak ada tambahan insentif dan bonus jika pekerjaan selesai tepat waktu, dan hal ini membuat saya dalam bekerja menjadi malas-malasan.

Selanjutnya, dalam menciptakan kepuasan kerja karyawan pimpinan harus dapat memberikan motivasi bagi para pekerja. Motivasi atau dorongan untuk bekerja sangat penting dalam penentuan tinggi rendahnya kerja perusahaan dan mempengaruhi kepuasan seorang pegawai dalam bekerja.

Berdasarkan uraian latar belakang di atas maka penulis tertarik untuk mengadakan penelitian tentang "Pengaruh Kepemimpinan Dan Motivasi Kerja Terhadap Kepuasan Kerja Karyawan Di PT Rahman Teknik Perkasa Bekasi". Dalam penelitian ini permasalahan dirumuskan sebagai berikut yaitu apakah Kepemimpinan berpengaruh terhadap Kepuasan Kerja Karyawan di PT Rahman Teknik, apakah Motivasi kerja berpengaruh terhadap Kepuasan Kerja Di PT Rahman Teknik dan apakah Kepemimpinan dan motivasi kerja secara bersama-sama berpengaruh terhadap Kepuasan Kerja Karyawan Di PT Rahman Teknik.

\section{TINJAUAN PUSTAKA \\ Kepuasan Kerja}

Menurut Robbins, Timothy Judge (2013 : 74) Job Satisfaction which describes a positive feeling about a job, resulting from an evaluation of its characteristics. Istilah kepuasan kerja menjelaskan perasaan positif tentang sebuah pekerjaan, yang berasal dari evaluasi atas karakteristiknya. Seseorang dengan tingkat kepuasan kerja yang tinggi memiliki perasaan yang positif tentang pekerjaannya, sementara seseorang yang tidak puas mempunyai perasaan yang negatif. Ketika orang-orang berbicara tentang sikap pekerjannya, mereka biasanya bermaksud berbicara tentang kepuasan bekerjanya. Pada kenyataannya, kedua hal ini seringkali digunakan secara terbalik atau berganti-ganti.

Sedangkan menurut Locke (Luthan 2011 : 141) definition of job satisfaction as involving cognitive, affective, and evaluative reactions or attitudes and states it is -a pleasurable or positive emotional state resulting from the appraisal of one's job or job experience.Yang artinya, definisi kepuasan kerja melibatkan aspek kognitif, afektif, dan reaksi evaluatif atau sikap dan menyatakan itu adalah keadaan emosi yang menyenangkan atau positif yang dihasilkan dari penilaian dari seseorang pekerjaan atau pengalaman kerja.

Schermerhorn (2010:73) Di antara banyak kuesioner kepuasan kerja yang tersedia yang telah digunakan selama dua tahun, yaitu Job Description Index (JDI) yang terdiri dari lima bagian dari kepuasan kerja yaitu:

1. The work itself-responsibility, interest, and growth (Pekerjaan itu sendiri-tanggung jawab, minat, dan pertumbuhan)

2. Quality of supervision-technical help and social support (Kualitas bantuan pengawasan teknis dan dukungan sosial)

3. Relationships with co-workers- social harmony and respect (Hubungan dengan harmoni rekan kerja-sosial dan rasa hormat)

4. Promotion opportunitieschances for further advancement (Promosi peluang-peluang untuk kemajuan lebih lanjut)

5. Pay-adequacy of pay and perceived equity vis-à-vis others (Gaji-kecukupan gaji dan perasaan sama dengan orang lain).

\section{Pengertian Kepemimpinan}

Menurut Daft (2015:5) kepemimpinan adalah :-Leadership is an influence relationship among leaders and followers who intend real changes and outcomes that reflect their shared purposes/|.Artinya Kepemimpinan adalah hubungan pengaruh antara pemimpin dan pengikut yang berniat perubahan nyata dan hasil yang mencerminkan tujuan bersama mereka.

Menurut Certo (2016 : 323) Leadership is the process of directing the behavior of others toward the accomplishment of an objective. Kepemimpinan adalah proses mengarahkan 
perilaku orang lain terhadap pemenuhan suatu objektif. Agar dapat mengarahakan orang lain, pemimpin harus mengetahui bagaimana pemimpin mendapat kekuasaan dan pengaruh yang digunkan untuk mengarahakan orang lain.

Menurut Dubrin (2010 : 395) Excellent global leaders have a leadership style that generate superior corporate performance in terms of four criteria 1). Profitability and productivity. 2) Continuity anf Efficiency, 3) commitment and morale 4) adaptability and innovation. Yang artinya para pemimpin global yang sangat baik memiliki gaya kepemimpinan yang menghasilkan kinerja perusahaan yang unggul dalam hal empat kriteria 1). Profitabilitas dan produktivitas. 2) Continuity anf Efisiensi, 3) komitmen dan semangat 4) kemampuan adaptasi dan inovasi.

\section{Pengertian Motivasi Kerja}

Menurut Daft(2016 : 552) Motivation refers to the forces either within or external to a person that arouse enthusiasm and persistence to pursue a certain course of action. Definisi formalnya, Motivasi mengacu pada kekuatan baik di dalam maupun eksternal untuk seseorang yang membangkitkan semangat dan ketekunan untuk mengejar tujuan tertentu.

Sejalan dengan pendapat Griffin dan Morhead (2014 : 90) Motivation is Menurut Amstrong (2012 : 117) Motivation is the strength and direction of behaviour and the factors that influence people to behave in certain ways in carrying out their work. Yang artinya Motivasi adalah kekuatan dan arahperilaku dan faktor- faktor yang mempengaruhiorang untuk berperilaku dalam cara tertentu dalam menjalankanpekerjaan mereka.

\section{Hipotesis Penelitian}

Berdasarkan kajian teoretis dan kerangka berpikir diatas, hipotesis dalam penelitian ini adalah sebagai berikut :

H1 :Kepemimpinan berpengaruh positi $f$ terhadap Kepuasan Kerja karyawan di PT Rahman Teknik.

H2 : Motivasi pegawai berpengaruh positif terhadap Kepuasan Kerja karyawan di PT Rahman Teknik.

H3 : Kepemimpinan dan motivasi pegawai berpengaruh positif secara bersamasamaterhadap Kepuasan Kerjakaryawan di PT
Rahman Teknik.

\section{METODOLOGI PENELITIAN}

Populasi dalam penelitian ini adalah karyawan bagian di pegawai PT Rahman Teknik. Sampel dalam penelitian adalah sebagian dari populasi. Teknik pengambilan sampel yang digunakan adalah Random Sampling, yaitu cara penarikan sampel yang dilakukan secara acak sederhana. Populasi target yang terjangkau adalah seluruh pegawai PT Rahman Teknik berjumlah 67 orang. Menghitung jumlah sampel menggunakan rumus Slovin. Diperoleh jumlah sampel $=40$ orang, Sedangkan untuk uji coba instrumen sebanyak 20 orang.

\section{HASIL PENELITIAN DAN PEMBAHASAN}

\section{Uji Validitas}

Dari nilai $r$ hitung dari semua variabel yang diuji bernilai terdapat 25 butir validatau bernilai lebih besar dari $r$ tabel yang memiliki nilai 0.444 dan 0 butir drop atau bernilai lebih kecil dari $r$ tabel yang memiliki nilai 0.444 sehingga dapat disimpulkan bahwa 25 butiran pertanyaan dari setiap variabel dalam penelitian ini dinyatakan valid.

Dari nilai $r$ hitung dari semua variabel yang diuji bernilai terdapat 25 butir validatau bernilai lebih besar dari $r$ tabel yang memiliki nilai 0.444 dan 0 butir drop atau bernilai lebih kecil dari $r$ tabel yang memiliki nilai 0.444 sehingga dapat disimpulkan bahwa 25 butiran pertanyaan dari setiap variabel dalam penelitian ini dinyatakan valid.

Dari nilai $r$ hitung dari semua variabel yang diuji bernilai terdapat 20 butir validatau bernilai lebih besar dari $r$ tabel yang memiliki nilai 0.444 dan 0 butir drop atau bernilai lebih kecil dari $r$ tabel yang memiliki nilai 0.444 sehingga dapat di simpulkan bahwa 25 butiran pertanyaan dari setiap variabel dalam penelitian ini dinyatakan valid.

\section{Uji Reliabilitas}

Hasil Nilai Cronbach's Alpha sebesar 0.922. Sesuai kriteria, nilai ini sudah lebih besar dari 0.60 , maka hasil dari kuesioner yang disebar memiliki tingkat realibilitas yang baik, atau dengan kata lain data hasil kuesioner yang disebar dapat dipercaya.

Hasil Nilai Cronbach's Alpha sebesar 
0.928 . Sesuai kriteria, nilai ini sudah lebih besar dari 0.60 , maka hasil dari kuesioner yang disebar memiliki tingkat realibilitas yang baik, atau dengan kata lain data hasil kuesioner yang disebar dapat dipercaya

Hasil Nilai Cronbach's Alpha sebesar 0.926 . Sesuai kriteria, nilai ini sudah lebih besar dari 0.60 , maka hasil dari kuesioner yang disebar memiliki tingkat realibilitas yang baik, atau dengan kata lain data hasil kuesioner yang disebar dapat dipercaya.

\section{Uji Normalitas}

Dalam uji normalitas ini menggunakan uji liliefors dengan melihat nilai signifikansi pada kolmogorov - smirnov. Kriteria pengujiannya adalah sebagai berikut: Jika nilai Signifikansi (Asym Sig 2 tailed) > 0,05, maka data berdistribusi normal dan Jika nilai Signifikansi (Asym Sig 2 tailed $<0,05$, maka data tidak berdistribusi normal.

Untuk melihat hasil yang lengkap sampel dari populasi berdistribusi normal atau tidak dapat dilihat pada tabel uji normalitas berikut.

Tabel 1.

Uji Normalitas

One-Sample Kolmogorov-Smirnov Test

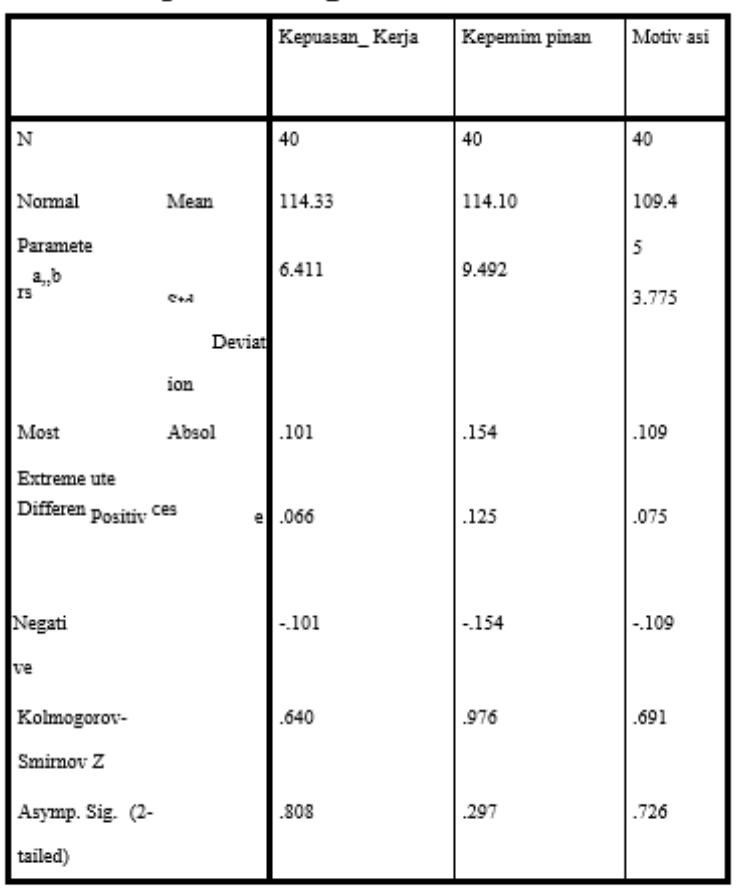

a. Test distribution is Normal.

b. Calculated from data.

Variabel Terikat Kepuasan Kerja

Uji normalitas terhadap
Kepuasan Kerja probabilitas Asymp. Sig. = 0,808 . Karena nilai signifikansi lebih besar daripada taraf uji penelitian (Sig $>\alpha$ yaitu $0,808>0,05)$ maka dapat disimpulkan bahwa data variabel yang diuji Kepuasan Kerja berdistribusi normal sehingga memenuhi persyaratan untuk analisis statistik inferensi.

\section{Normalitas Variabel Bebas Kepemimpinan}

Uji normalitas terhadap variabel bebas Kepemimpinan menghasilkan nilai dengan probabilitas Asymp. Sig. $=0,297$. Karena nilai signifikansi Kolmogorov-Smirnov lebih besar daripada taraf uji penelitian (Sig $>\alpha$ yaitu 0,297> 0,05) maka dapat disimpulkan bahwa data variabel yang diuji Kepemimpinan berdistribusi normal sehingga memenuhi persyaratan untuk analisis statistik inferensi.

\section{Normalitas Variabel Bebas Motivasi}

Uji normalitas terhadap variabel bebas Motivasi dengan probabilitas Asymp. Sig. = 0,726 . Karena nilai signifikansi KolmogorovSmirnovlebih besar daripada taraf uji penelitian (Sig > $\alpha$ yaitu $0,726>0,05$ ) maka dapat disimpulkan bahwa data variabel yang diuji Motivasi berdistribusi normal sehingga memenuhi persyaratan untuk analisis statistik inferensi.

\section{Analisis Regresi Linear Sederhana dan Berganda}

Berdasarkan perhitungan analisis regresi linier berganda yang dilakukan melalui statistik dengan menggunakan program SPSS 17, maka diperoleh hasil sebagai berikut. 
Tabel 2

Hasil Analisis Regresi Linear Sederhana

\section{Coefficients $^{\mathrm{a}}$}

\begin{tabular}{|c|c|c|c|c|c|}
\hline \multirow[b]{2}{*}{ Model } & \multicolumn{2}{|c|}{$\begin{array}{l}\text { Unstandardi } \\
\text { z ed } \\
\text { Coefficients }\end{array}$} & \multirow{2}{*}{\begin{tabular}{|c}
$\begin{array}{c}\text { Standardi } \\
\mathrm{z} \text { ed } \\
\text { Coefficient } \\
\mathrm{s}\end{array}$ \\
Beta
\end{tabular}} & \multirow[b]{2}{*}{$\mathrm{t}$} & \multirow{2}{*}{ Sig } \\
\hline & B & $\begin{array}{l}\text { Std. } \\
\text { Error }\end{array}$ & & & \\
\hline 1 (Constant) & $\begin{array}{c}65.13 \\
7\end{array}$ & 9.656 & & $\begin{array}{c}6.74 \\
6\end{array}$ & $\begin{array}{c}.00 \\
0\end{array}$ \\
\hline $\begin{array}{c}\text { Kepemimpin } \\
\text { an }\end{array}$ & .431 & .084 & .638 & $\begin{array}{c}5.11 \\
1\end{array}$ & $\begin{array}{c}.00 \\
0\end{array}$ \\
\hline
\end{tabular}

a. $\quad$ Dependent Variable: Kepuasan_Kerja Sumber: Data Hasil Output SPSS

Berdasarkan output SPSS di atas, maka diperoleh persamaan regresi Linear sebagai berikut : $\mathrm{Y}=65.137+0,431 \mathrm{X} 1$. Model tersebut menunjukkan arti bahwa:

1. Konstanta $=65.137$

Jika variable Kepemimpinan diasumsikan tetap maka Kepuasan Kerja akan meningkat sebesar65.137.

2. Koefisien Kepemimpinan X1 Nilai koefisien Kepemimpinan sebesar 0,431. Menyatakan bahwa setiap terjadi kenaikan 1 skor untuk Kepemimpinan akan diikuti terjadi kenaikan Kepuasan Kerja sebesar 0,431.

\section{Analisis Regresi Linear Sederhana Motivasi terhadap Kepuasan Kerja}

Tabel 3.

Hasil Analisis Regresi Linear Sedehana

\section{Coefficients $^{\mathbf{a}}$}

\begin{tabular}{|c|c|c|c|c|c|}
\hline \multirow{2}{*}{ Model } & \multicolumn{2}{|c|}{$\begin{array}{c}\text { Unstandardize d } \\
\text { Coefficients }\end{array}$} & $\begin{array}{c}\text { Standardize } \\
\text { d Coefficients }\end{array}$ & & \\
\cline { 2 - 5 } & $\mathrm{B}$ & $\begin{array}{c}\text { Std. } \\
\text { Error }\end{array}$ & Beta & $\mathrm{t}$ & Sig. \\
\hline $\begin{array}{c}1 \text { Constant } \\
\text { ) } \\
\text { Motivasi }\end{array}$ & -2.065 & 23.517 & & -.088 & .93 \\
& 1.063 & .215 & .626 & 4.95 & .00 \\
2 & 0 \\
\hline
\end{tabular}

a. $\quad$ Dependent Variable: Kepuasan_Kerja Sumber: Data Hasil Output SPSS
Berdasarkan output SPSS di atas, maka diperoleh persamaan regresi Linear sebagai berikut : $Y=-2,065+1,063 X 2$. Model tersebut menunjukkan arti bahwa:

1. Konstanta $=-2,065$. Jika variable Motivasi diasumsikan tetap maka Kepuasan Kerja akan menurun sebesar -2,065.

2. Koefisien Kepemimpinan X1 Nilai koefisien motivasi sebesar 1,063. Menyatakan bahwa setiap terjadi kenaikan 1 skor untuk motivasi akan diikuti terjadi kenaikan Kepuasan Kerja sebesar 1,063.

\section{Analisis Regresi Linear Berganda Kepemimpinan dan Motivasi terhadap Kepuasan Kerja}

Tabel 4

Hasil Analisis Regresi Linear Berganda

\section{Coefficients $^{\mathrm{a}}$}

\begin{tabular}{|c|c|c|c|c|c|c|c|}
\hline \multirow[b]{2}{*}{ Model } & \multicolumn{2}{|c|}{$\begin{array}{l}\text { Unstandar } \\
\text { dized } \\
\text { Coefficien ts }\end{array}$} & \multirow{2}{*}{$\begin{array}{c}\begin{array}{c}\text { Standar } \\
\text { dized } \\
\text { Coeffici } \\
\text { ents }\end{array} \\
\text { Beta }\end{array}$} & \multirow[b]{2}{*}{$\mathrm{t}$} & \multirow[b]{2}{*}{ Si g. } & \multicolumn{2}{|c|}{$\begin{array}{c}\text { Collinearit y } \\
\text { Statistics }\end{array}$} \\
\hline & B & $\begin{array}{l}\text { Std. } \\
\text { Erro r }\end{array}$ & & & & $\begin{array}{c}\text { Tolera } \\
\text { nce }\end{array}$ & VI F \\
\hline $\begin{array}{c}1 \\
\text { (Constant } \\
\text { ) }\end{array}$ & $\begin{array}{c}5.32 \\
6\end{array}$ & $\begin{array}{c}19.8 \\
12\end{array}$ & & $\begin{array}{c}26 \\
9\end{array}$ & $\begin{array}{l}.7 \\
90\end{array}$ & & \\
\hline $\begin{array}{c}\text { Kepemim } \\
\text { pinan }\end{array}$ & .317 & .078 & .469 & $\begin{array}{l}4.0 \\
78\end{array} \mid$ & $\begin{array}{c}.0 \\
00\end{array}$ & .858 & $\begin{array}{l}1.1 \\
66\end{array}$ \\
\hline Motivasi & .763 & .195 & .449 & $\begin{array}{l}3.9 \\
10\end{array} \mid$ & $\begin{array}{l}.0 \\
00\end{array}$ & .858 & $\begin{array}{l}1.1 \\
66\end{array}$ \\
\hline
\end{tabular}

a. Dependent Variable: Kepuasan_Kerja

Sumber: Data Hasil Output SPSS

Berdasarkan output SPSS di atas, maka diperoleh persamaan regresilinear berganda sebagai berikut: $\mathrm{Y}=-5,326+0,317 \mathrm{X} 1+0,763$ $\mathrm{X} 2$. Model tersebut menunjukkan arti bahwa:

1. Konstanta $=-5,326$. Jika variable Kepemimpinan dan Motivasidiasumsikan tetap maka Kepuasan Kerja akan menurun sebesar -5,326.

2. Koefisien Kepemimpinan X1 Nilai koefisien Kepemimpinansebesar 0,317. Menyatakan 
bahwa setiap terjadi kenaikan 1 skor untuk Kepemimpinan akan diikuti terjadi kenaikan Kepuasan Kerja sebesar 0,317.

3. Koefisien Motivasi X2. Nilai koefisien Motivasimenunjukan angka sebesar 0,763. menyatakan bahwa apabila terjadi kenaikan 1 skor untuk Motivasi akan diikuti dengan terjadi kenaikan Kepuasan Kerjasebesar 0,763 .

\section{Hasil Uji Hipotesis}

\section{Uji Parsial dan Simultan Variabel Bebas}

Untuk mengetahui hubungan variabel bebas Kepemimpinan dan Motivasidengan variabel terikat yaitu Kepuasan Kerjamaka perlu dilakukan uji t. Pengujian secara parsial dapat dilihat dari uji t, apabila nilai probabilitasnya < 0,05, H0 ditolak yang berarti ada pengaruh yang signifikan. Hasil uji parsial dapat dilihat pada tabel berikut ini:

Tabel 5

Hasil Analisis Uji t

\section{Coefficients ${ }^{\mathbf{a}}$}

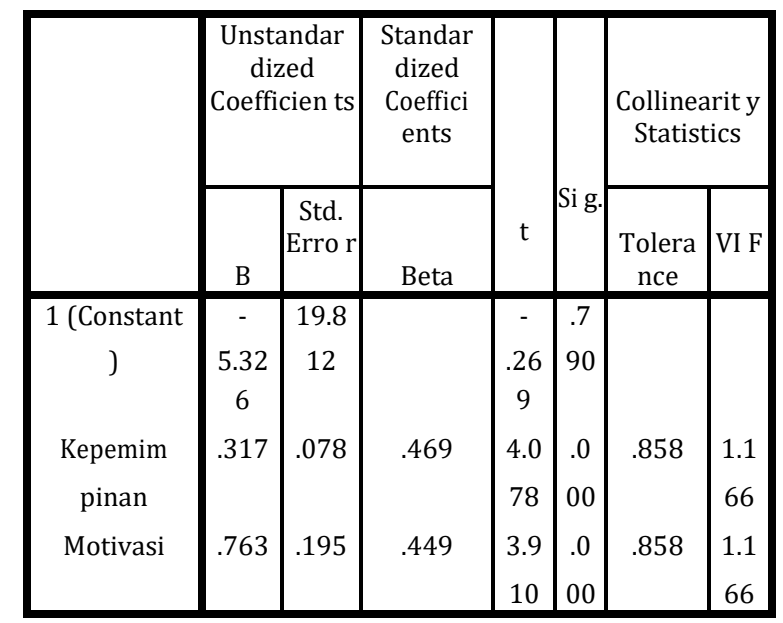

a. Dependent Variable: Kepuasan_Kerja

Sumber: Data Hasil Output SPSS

\section{Hasil Uji Hipotesis Variabel Kepemimpinan Terhadap Kepuasan Kerja}

Dari hasil pengujian dengan hipotesis secara parsial uji t signifikansi yang terlihat pada tabel di atas bahwa 1variabel Kepemimpinan (X1) diperoleh nilai t-hitung sebesar 4,078. Sedangkan statistik table ( $\mathrm{t}$ tabel) sebesar 2.021. Sehingga dapat ditarik kesimpulan bahwa variabel bebas Kepemimpinan secara parsial memiliki pengaruhdan relative signifikan terhadap Kepuasan Kerjapada pegawai.

\section{Hasil Uji t MotivasiTerhadap Kepuasan Kerja}

Dari hasil pengujian dengan hipotesis secara parsial uji t signifikansi yang terlihat pada tabel di atas bahwa variabel Motivasi(X2) diperoleh nilai t-hitung sebesar 3,910. Sedangkan statistik table (t tabel) sebesar 2,021. Sehingga dapat ditarik kesimpulan bahwa variabel bebas Motivasisecara parsial memiliki pengaruh dan relatif signifikan terhadap Kepuasan Kerja pada pegawai.

\section{Hasil Uji Simultan Variabel Kepemimpinan dan Motivasi Terhadap Kepuasan Kerja}

Untuk mengetahui pengaruh variabel Kepemimpinan dan Motivasi terhadap variabel terikat yaitu Kepuasan Kerjamaka perlu dilakukan uji F. pengujian secara simultan dapat dilihat dari uji f, apabila nilai probabilitasnya $<0,05$, Ho ditolak yang berarti ada pengaruh yang signifikan. Hasil uji simultan dapat dilihat pada tabel berikut ini:

Tabel 5

Hasil Analisis Uji F

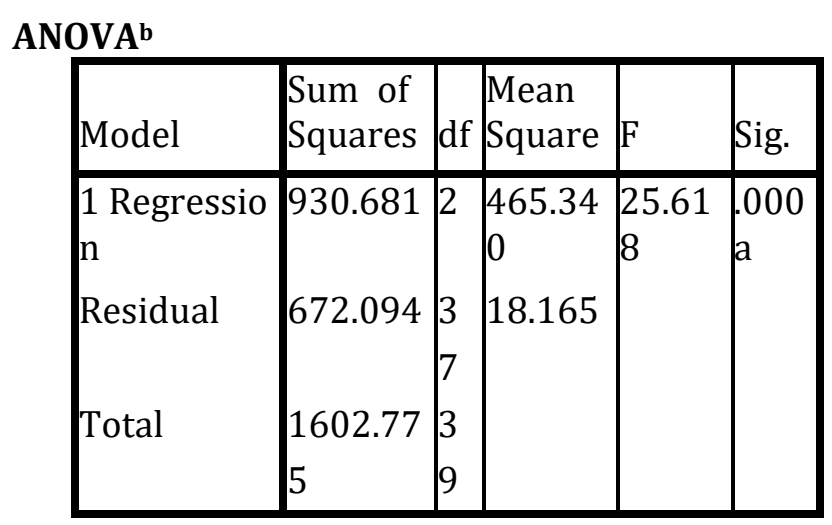

a. Predictors: (Constant), Motivasi,

Kepemimpinan

b. Dependent Variable: Kepuasan_Kerja

Dari hasil pengujian dengan hipotesis secara Simultan uji F signifikansi yang terlihat pada tabeldi atas bahwa variabel Kepemimpinan dan Motivasi diperoleh nilai fhitung sebesar 25,618. Sedangkan statistik table (F tabel) sebesar3,23.Sehingga dapat 
ditarik kesimpulan bahwa variabel bebas Kepemimpinan dan Motivasisecara simultan memiliki pengaruh positif dan relatif signifikan terhadap Kepuasan Kerjapegawai.

\section{PEMBAHASAN}

Penelitian ini dilakukan untuk memperoleh pemahaman yang lebih lengkap tentang pengaruh Kepemimpinandan Motivasi terhadap Kepuasan Kerjapada pegawai. Berikut ini akan disampaikan pembahasan hasil penelitian dengan mengacu kepada tujuan penelitian.

\section{Kepemimpinan Terhadap Kepuasan Kerja}

Dari hasil pengujian dengan hipotesis secara parsial uji t signifikansi yang terlihat pada tabel di atas bahwa variabel Kepemimpinan (X1) diperoleh nilai t- hitung sebesar 4,078. Sedangkan statistik table $(\mathrm{t}$ tabel) sebesar 2.021. Sehingga dapat ditarik kesimpulan bahwa variabel bebas Kepemimpinan secara parsial memiliki pengaruh dan relatif signifikan terhadap Kepuasan Kerja pada pegawai. Menurut Daft (2015:5) kepemimpinan adalah : -Leadership is an influence relationship among leaders and followers who intend real changes and outcomes that reflect their shared purposes//.Artinya Kepemimpinan adalah hubungan pengaruh antara pemimpin dan pengikut yang berniat perubahan nyata dan hasil yang mencerminkan tujuan bersama mereka dan dengan menggunakan indikator berorientasi kepada profit, memiliki prilaku yang produktif, bekerja secara efisien, bekerja secara berkelanjutan, memiliki komitmen tinggi 6) memiliki moral yang baik, 7) memiliki inovasi 8) mampu beradaptasi mengikuti zaman diharapkan dapat memberikan masukan kepada perusahaan agar dapatmemperbaiki tipe kepemimpinan yang lebih baik lagi.

Pengaruh positif Kepemimpinan terhadap Kepuasan Kerja, maka semakin tinggi nilai Kepemimpinan yang diterapkan pada diri pegawai, maka kecenderungan melakukan Kepuasan Kerjasemakin tinggi.

\section{Motivasi Terhadap Kepuasan Kerja}

Hal ini sesuai dengan pendapat Daft(2016 : 552) Motivation refers to the forces either within or external to a person that arouse enthusiasm and persistence to pursue a certain course of action. Di antara banyak kuesioner kepuasan kerja yang tersedia yang telah digunakan selama dua tahun, yaitu Job Deskription Index (JDI) yang terdiri dari lima bagian dari kepuasan kerja yaitu:

1. The work itself-responsibility, interest and growth (Pekerjaan itu sendiri-tanggung jawab, keuntungan dan pertumbuhan);

2. Quality of supervision - technical help and social support (Kualitas bantuan pengawasan teknis dan dukungan sosial);

3. Relationships with co-workers- social harmony and respect (Hubungan yang harmoni rekan kerja-sosial dan rasa hormat)

4. Promotionopportunities - chances for further advancement (Promosi peluang-peluang untuk kemajuan lebih lanjut)

6. Pay-adequacy of pay and perceived equity vis-à-vis others (Gaji-kecukupan gaji dan persamaan hak).

Pengaruh positif Motivasi terhadap Kepuasan Kerja, maka semakin tinggi nilai Motivasiyang diterapkan pada diri pegawai, maka kecenderungan melakukan Kepuasan Kerja semakin tinggi.

\section{Kepemimpinan dan MotivasiTerhadap Kepuasan Kerja}

Terjalinnya komunikasi dua arah antara pimpinan dengan bawahan akan terdapat keserasian antara pimpinan dan bawahan dalam pencapaian tujuan organisasi. Unsur manusia merupakan unsur yang menentukan berhasil tidaknya pencapaian tujuan organisasi. Oleh karena itu, perlu dibina hubungan antar manusia yang sebaik-baiknya. Hal tersebut pada akhirnya dapat menjadi tim yang penuh kesadaran di antara mereka tanpa adanya paksaan. Dengan demikian, pemimpin harus memberikan perhatian kepada bawahan dalam melaksanakan pekerjaan, agar bawahan merasa diperlukan kehadirannya dan bukan dianggap sebagai alat atau mesin dalam organisasi. Motivasi kerja ialah usaha untuk menunjukkan apa yang membuat orang-orang termotivasi untuk bekerja. Dengan cara 
memperhatikan, mengidentifikasi kebutuhan dan mengarahkan mereka, karena pada dasarnya orang ingin diprioritaskan. Mereka adalah orang dengan tipe-tipe insentif, dimana orangbekerja keras dalam rangka mencapai tujuan serta melakukan yang terbaik. Pengaruh positif Kepemimpinan dan Motivasiterhadap Kepuasan Kerja, maka semakin tinggi nilai Kepemimpinan dan Motivasi kerjayang diterapkan pada diri pegawai, maka kecenderungan mendapatkan Kepuasan Kerja semakin tinggi

\section{KESIMPULAN}

Berdasarkan hal-hal telah diuraikan dalam bab-bab sebelumnya, peneliti dapat memberikan kesimpulan sebagai berikut, bahwa kepemimpinan berpengaruh positif dan signifikan terhadap Kepuasan Kerja pada pegawai PT Rahman Teknik. Artinya, Kepemimpinan pada perusahaan jika diterapkan dan dipahami akan berdampak positif terhadap pekerjaan pegawai di perusahaan, seperti berorientasi kepada profit. Memiliki berperilaku yang produktif, bekerja secara efisien, bekerja secara berkelanjutan, memiliki komitmen tinggi, memiliki moral yang baik, memiliki inovasi dan mampu beradaptasi mengikuti zaman. Dikatakan juga diperoleh persamaan regresi Linearsederhana sebagai berikut: $Y=65.137+$ $0,431 \mathrm{X} 1$.

Motivasi kerja berpengaruh positif terhadap Kepuasan Kerja di PT Rahman Teknik Perkasa. Dengan cara memperhatikan, mengidentifikasi kebutuhan dan mengarahkan mereka. Seperti, jenjang karir yang jelas, gaji yang sesuai dengan peraturan pemerintah, adanya bonus atau hadiah pada saat pekerjaan selesai tepat waktu, jaminan rasa aman seperti tersedianya asuransi keselamatan dan kesehatan kerja.Di dalam SPSS diperoleh persamaan regresi Linear sederhana sebagai berikut : $Y=-2,065+1,063 X 2$. Kepemimpinan dan Motivasi secara bersama-sama juga berpengaruh positif dan signifikan terhadap Kepuasan Kerja pada pegawai PT Rahman Teknik. artinya Kepemimpinan adalah seorang yang mempengaruhi orang lain untuk mencapai tujuan. Makin besar pengaruh seorang pemimpin, makin besar pula pengikutnya.Dan makin sukses tujuan-tujuan yang dapat dicapai makin terbukti kepemimpinannya, kepemimpinan yang sesuai dengan kondisi perkembangan zaman dan job desk sesuai dengan jenis perusahaan diharapkan mampu memberikan solusi yang baik dalam penyelesaian proyek yang tepat waktu efektif dan efisien. Dan motivasi yang diberikan kepada karyawan lebih kepada kebutuhan yang harus tercover seperti gaji yang sesuai dengan peraturan pemerintah dan kebutuhan rasa aman dari bahaya pekerjaan dan insentif yang sesuai jika proyek selesai tepat waktu. Dalam SPSS diperoleh persamaan regresi linear berganda sebagai berikut : $\mathrm{Y}=$ $5,326+0,317 \mathrm{X} 1+0,763 \mathrm{X} 2$

\section{SARAN}

Berdasarkan kesimpulan dari hasil penelitian hubungan Kepemimpinandan Motivasiterhadap Kepuasan Kerjapada pegawai PT Rahman Teknik Perkasa Bekasidapat dikemukakan beberapa saran, sebagai berikut, yaitu bahwa dalam upaya PT Rahman Teknik Perkasa Bekasi meningkatkan Kepuasan Kerja pegawai untuk dapat meningkatkan Kepuasan Kerja kerja karyawan PT Rahman Teknik Perkasa Bekasi, penulis menyarankan perusahaan lebih menanamkan nilai-nilai kepemimpinan, seperti memperbaiki manajemen proyek dan pemberian beban kerja kepada karyawan disesuaikan dengan jabatannya.

Dalam upaya PT Rahman Teknik Perkasa Bekasi meningkatkan Kepuasan Kerja pegawai,penulis menyarankanuntuk memperbaiki sistem manajemen perekrutan dengan pemberian surat kontrak yang jelas kepada karyawan, memperhatikan nilai insentif karyawan dalam menyelesaikan pekerjaannya dan memberikan jenjang karir jika karyawan sudah memenuhi kriteria. Pada penelitian berikutnya disarankan mengkaji dari perilaku organisasi antar pribadi.

\section{DAFTAR PUSTAKA}

Alamsyah, D. P., Suhartini, T., Rahayu, Y., Setyawati, I., \& Hariyanto, O. I. B. (2018, November). Green advertising, green brand image and green awareness for environmental products. In IOP Conference Series: Materials Science and Engineering (Vol. 434, No. 1, p. 012160). IOP Publishing.

Annie McKee. Management: a focus on leaders. 
Pearson Education, Inc. New York: 2012.

Armstrong's. Handbook of Human Resource Management Practice Twelfth edition, Kogan Page. New Jersey: 2012.

Colquitt, Jason Jeffery Lepine. Organizational Behavior: Improving Performance And Commitment In The Workplace. New York: McGraw-Hill Companies, Inc, 2015.

Daft Richard L. Management, Twelfth Edition. Cengage Learning. New York: 2016.

DuBrin Andrew. Principle of Leadership. Sixth Edition. South Western Cengage Learning: 2010.

Ferell Linda. Business: A Changing World, Tenth Edition. Mc Graw Hill Education. New York: 2016.

Gibson. Organizations Behavior, Structure, Processes. Mcgrawhill, New York: 2009.

Griffin. W. Ricky. Fundamentals of Management Eighth Edition. Cengage Learning: 2016.

Hitt, Michael A. Management 3Rd Edition. Pearson Education, Inc: 2012.

Luthans, Fred. Organizational behavior : an evidence-based approach 12th ed. McGraw-Hill Companies, Inc. 2011.

Richard L. Daft, The Leadership Experience, Third Edition (South Western; Thomson 2015.

Ricky W. Griffin and Gregory Moorhead. Organizational Behavior: Managing People and
Organizations, Eleventh Edition. SouthWestern, Cengage Learning: 2012.

Robert L Mathis, Human Resource Management, Thompson South Western. Ohio: 2011.

Samuel C. Certo and S. Trevis Certo. Modern Management: Concepts and Skills, 14 Edition. Pearson Education Limited, 2016.

Schermerhorn, Oraganizational Behavior 10/E, Wiley Jefferson City 2010

Setyawati, I., \& Amelia, R. (2018). The Role of Current Ratio, Operating Cash Flow and Inflation Rate in Predicting Financial Distress: Indonesia Stock Exchange. Jurnal Dinamika Manajemen, 9(2), 140-148.

Setyawati, I. (2016). Determinants of Growth and Profitability by Bank Specific Variable and Market Stucture in Islamic Banking in Indonesia. Academy of Strategic Management Journal, 15, 1-14.

Stephen Robbins and Mary Coulter. Management $13^{\text {th }}$ Edition, Person International Edition, New Jersey, 2016

Stephen Robbins, Timothy Judge, Organizational Behavior $13^{\text {th }}$ Edition, Person International Edition, New Jersey, 2013

Steven L. McShane and Mary An Von Glinow, Organizational Behavior, Fourth Edition (New York: McGraw- Hill Companies, Inc, 2010. 